\title{
Characterization of Thin Alluvial Bed Aquifers in Manggar River Balikpapan East Kalimantan Indonesia
}

\author{
Totok Sulistyo ${ }^{1 *}$, Ali Abrar ${ }^{2}$ \\ ${ }^{1}$ Civil Engineering Dept., Politeknik Negeri Balikpapan \\ ${ }^{2}$ Electronic Dept., Politeknik Negeri Balikpapan \\ "totok.sulistyo@poltekba.ac.id
}

\begin{abstract}
Manggar Village is suburban, located in District of East Balikpapan, East Borneo Indonesia. In dry season, clean water crisis always hit this area. Therefore in order to full fill the need of water for domestic use the inhabitant of this area use dug well water. Dug well water comes from the upper most ground water that is stored and transmitted by relatively thin layer of alluvium deposit. In this research surface elevation measurement was done to control the elevation of dug well so that the depth of dynamic water level $(D W L)$ could be determined accurately. The equipotential map was made based on the $D W L$, then flow line can be drawn and gradient hydraulics $(i)$ can be calculated. Coefficient of permeability $(k)$ that were resulted from fall head test has shown value $1.284 \times 10^{-3}$ up to $11.45 \times 10^{-3} \mathrm{~cm} / \mathrm{sec}$ which gradually increases toward beach. According to the results of serial test and calculation the ground water transmissibility and velocity increases toward the beach. Generally groundwater has high hardness. The groundwater close to the beach has been mixed with sea water.
\end{abstract}

Keyword: groundwater, unconfined aquifer, transmissivity, hydraulic conductivity.

\section{Introduction}

In 2012, The inhabitants of East Kalimantan District more than 59,959 persons, and more than a half of them are inhabiting Manggar and Manggar Baru Village. If one person needs water 130 liters/day [1], it means this area need more than 3,897,335 liters per day.

Clean water of this area mostly is supplied by drinking water company that frequently lack of raw water especially in dry season. So crisis of clean water always happens in this area when it is in dry season more than one month.

Therefore in order to meet the need of clean water for bathing, washing and toilet use most inhabitant of this area uses water from dug well. The depth of dug wells are between 2 up to 3 meters, and water of dug wells comes from the upper most layer of geologic unit that is known as alluvium deposits. This unit is contained mix between silt sand and gravel materials and it is laying over the angular unconformities above the late Miocene of Kampung Baru Formation that's dominated by claystone and silt stone[2], so can be considered as impermeable beds. Having catered the need of water during crisis of clean water, it is interesting to be further studied its potency and parameters.

The research objective is to determine characters of unconfined aquifers such as equipotential pattern and flow direction. So that parameters of aquifer such as hydraulic conductivity, velocity and transmissibility can be calculated. This research is also aimed to determine where is the buffer area that should be preserved to make aquifer keeps recharged. Because long-term recharge quantities (decade to century scales) that determine the sustainability of these water resources [3]. And this research is also aimed so that no more 
biological contaminated or salt water intrusion in this thin aquifer. Having used for domestic water supply, alluvial aquifers is often compromised by excessive salinity [4].

Research was carried out in Manggar dan Manggar Baru Village. Administratively the research area is located in East Balikpapan District, East Kalimantan, Indonesia. According to the Development Planning Board of Balikpapan City, it will be developed as fishing industry Zone.

The natural boundaries of alluvial unconfined aquifer Manggar are beach in southeast, river in northeast, hilly morphology in northwest, and river in southwest (see Fig.1).

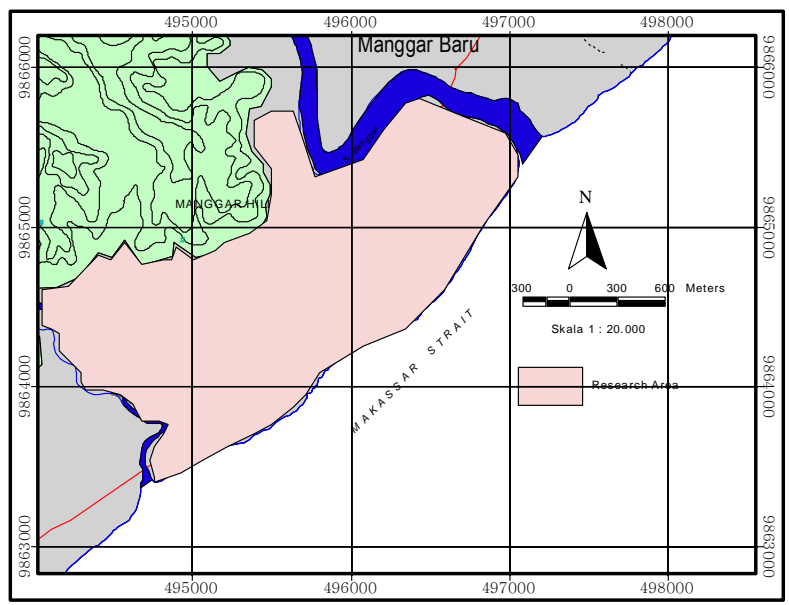

Figure 1. Natural border of geo hydrologic system of unconfined aquifer in the research area.

\section{Research Method}

Before coming to the conclusion, this research had been started by previous works involving many activities, starting from desk study, collecting data, analyzing and drawing conclusion. Elevation measurement using total station with polygon method, well depth measurement, DWL calculation, equipotential contouring, flow line drawing and maps overly using geographical information system method were employed in process of collecting data. Compilation of raster, vectors and database in Because GIS can be used to georeference all imported Raster Images into Vector Images.
The location of wells, springs, wastewater treatment plants, water samples in the study area were added as points to the active theme based on their coordinates[5]. In order to get aquifers and water parameters, systematic field sampling (across line) and laboratory test were also involved. Value of $\mathrm{k}$ was determined by head fall test while physical, chemical and biological parameters was done by Laboratory of Sucofindo Balikpapan.

In order to have better knowledge of aquifer and portray characteristic of aquifers in graphical presentation, studio works have been employed during the research. They were consisted of digitizing map, overlaying map, drafting cross section and making thematic map.

Analytic step are made based on collected data, map overlying, other portraying graphical presentation and result of calculation. Finally unconfined aquifer can be characterized quantitatively and descriptively.

\section{Result and Discussion}

After knowing of coordinate, elevation and depth of dug well through serial total station survey (see Fig.2).

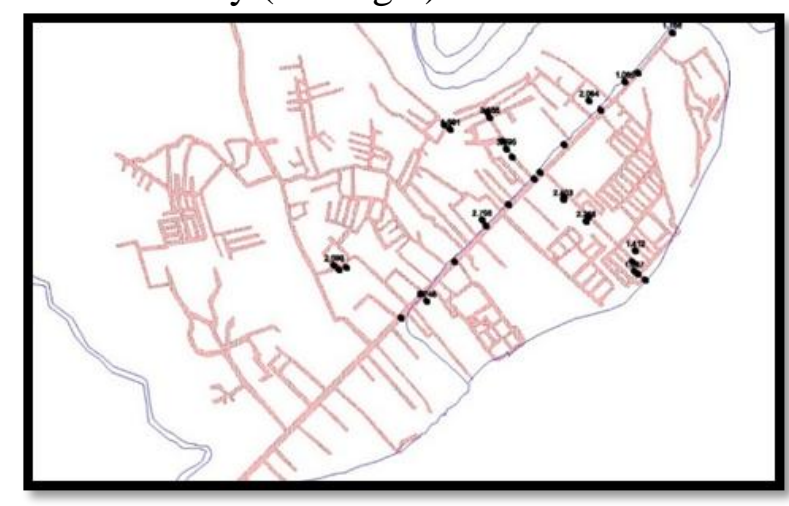

Figure 2. Location of elevation and depth of well measurement

Furthermore DWL can be determined through following formula:

$D W L=Z-D$.

Where $\mathrm{Z}=$ elevation of ground surface

$\mathrm{D}=$ depth of ground water surface 
Result of Calculation of DWL as listed in Table 1.

Table 1. List of DWL measured dug well

\begin{tabular}{cccccc}
\hline Cd & Easting $(\mathbf{m})$ & Northing & Elev. & Depth & DWL \\
\hline S1 & 495868.68 & 9865151.73 & 2.431 & 0.87 & 1.561 \\
S2 & 496039.201 & 9865203.519 & 4.555 & 1.4 & 3.155 \\
S3 & 496111.012 & 9865066.703 & 4.385 & 0.79 & 3.595 \\
S4 & 496356.018 & 9864846.759 & 3.253 & 0.85 & 2.403 \\
S5 & 496455.211 & 9864754.242 & 2.608 & 0.35 & 2.258 \\
S6 & 496667.96 & 9864627.339 & 2.332 & 0.92 & 1.412 \\
S7 & 496663.923 & 9864536.94 & 2.157 & 1.07 & 1.087 \\
S8 & 496467.615 & 9865275.247 & 3.074 & 0.99 & 2.084 \\
S9 & 496623.492 & 9865356.542 & 2.495 & 1.41 & 1.085 \\
S10 & 496827.592 & 9865570.332 & 2.576 & 1.41 & 1.166 \\
S11 & 496005.369 & 9864758.483 & 3.788 & 0.99 & 2.798 \\
S12 & 495765.732 & 9864408.139 & 3.588 & 0.84 & 2.748 \\
S13 & 495365.887 & 9864564.009 & 3.296 & 0.7 & 2.596 \\
\hline \multicolumn{7}{c}{ Note : measured in Juli $16^{\text {th }} 2016$} & & &
\end{tabular}
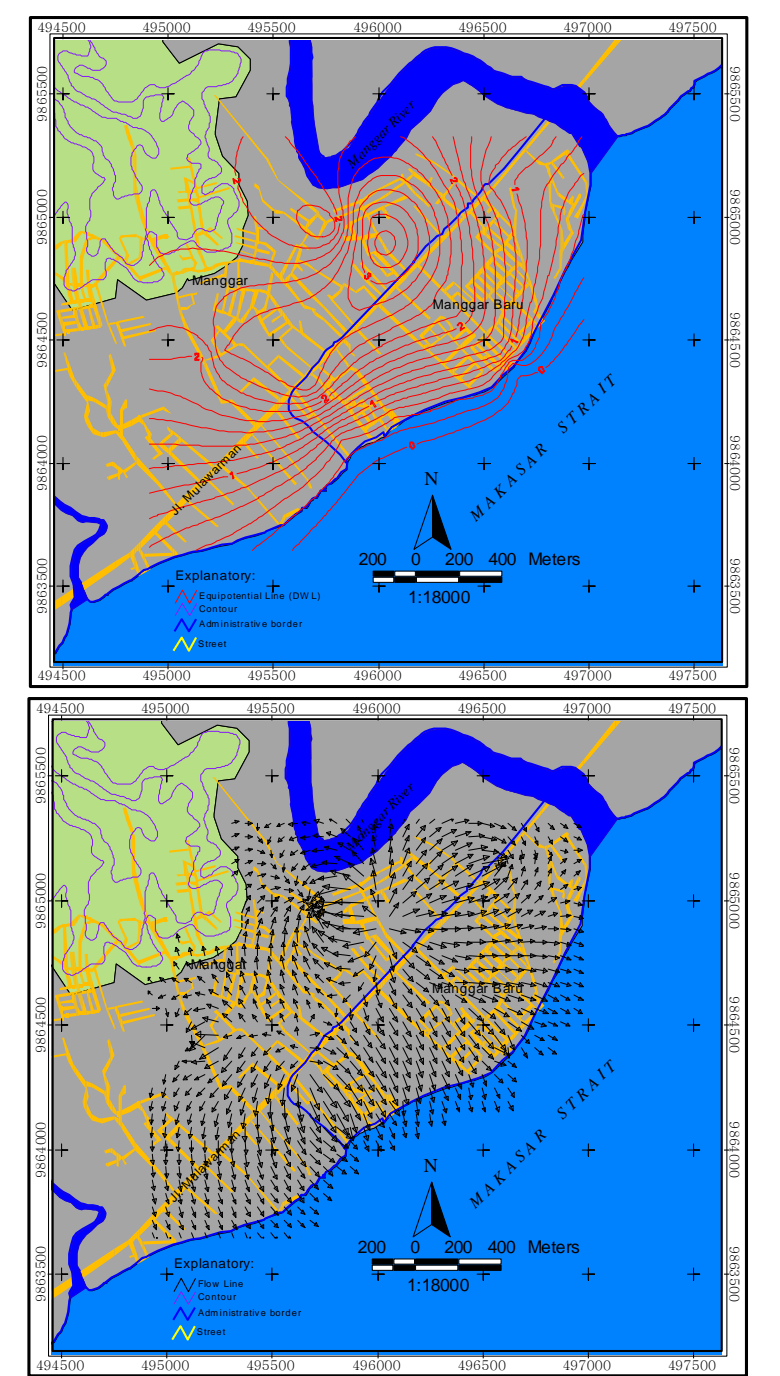

Figure 3. Map of equipotential line and Flow line map (flow direction)

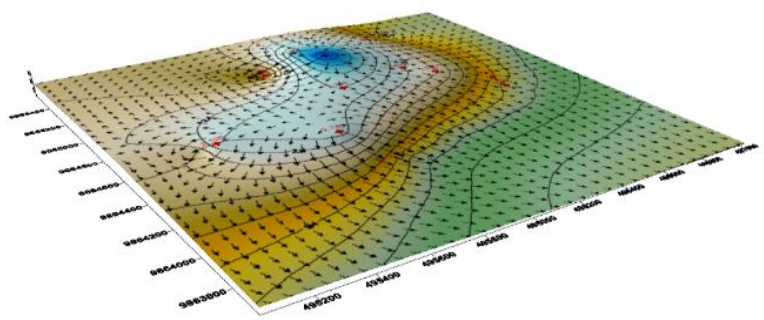

Figure 4. Three Dimensional Model of Overlay of Equipotential and Flow Line.

From Fig.3and 4 can be seen that flow pattern of ground water is radial from center toward entire border of aquifer system. and at the border of aquifer against Mangar River, Equipotential more than 0 that means DWL is higher than level of Manggar River (level of Manggar River equals with sea water level) this proved in the time of measurement Manggar River get supply of water from discharged ground water, therefore it can be classified as gaining stream type. Its condition is proved by Fig.5.

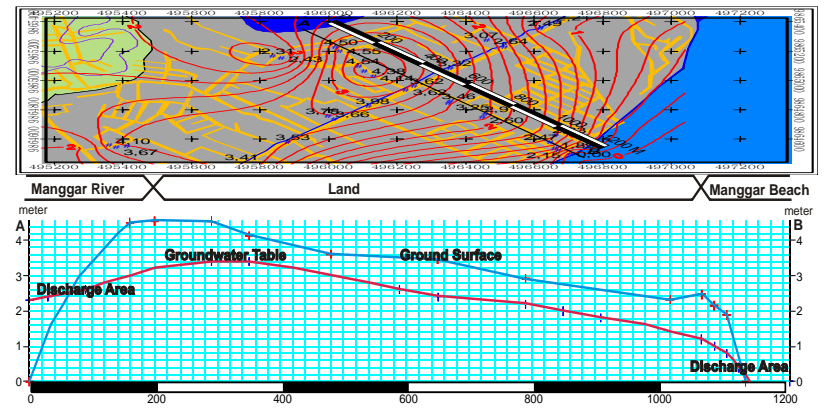

Figure 5. Profile of ground surface morphology and groundwater table (horizontal : vertical $=1$ : $50)$.

Based on observation and morphological interpretation, geological map of research area can be revised especially contact border of alluvial and older formation. Having deposited recently, its border follow contour line rather than straight line see Fig.6. 


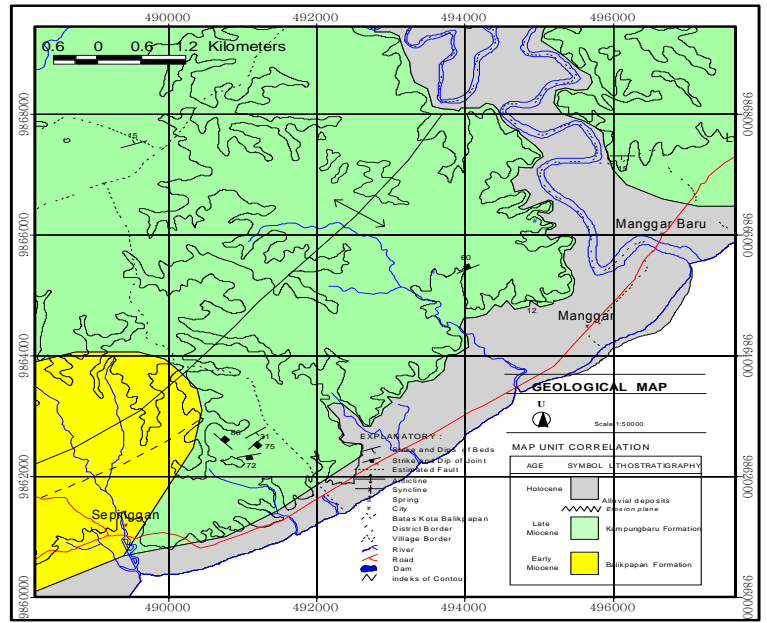

Figure 6. Revised geological map of research area and its vicinity.

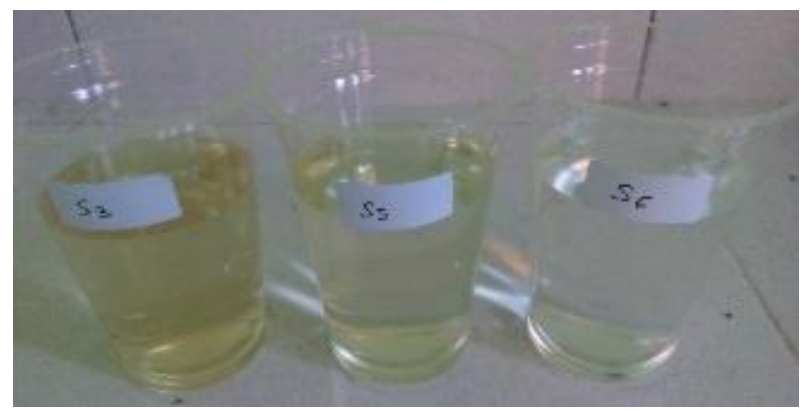

(a)

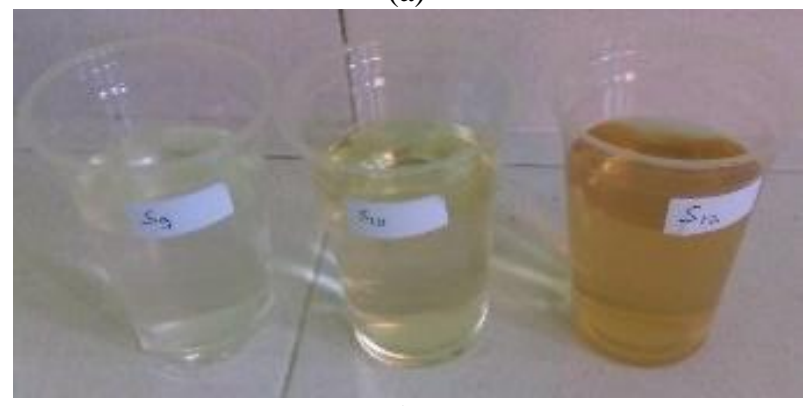

(b)

Figure 7. Color of Water : a) from S3 to S6 the land toward the beach, b) from S9 to S12 the bank of Manggar River toward land.

Visual observation of ground water from dug well from upstream (peak of equipotential line) toward downstream has shown water increasingly cleaner toward downstream (beach) see Fig.7. Although they are cleaner but sample of S6 and S9 are brackish water. From analysis of hydrogeology this area is interface of fresh water and seawater. And why groundwater is cleaner toward beach, it is caused by content of aquifers that toward beach aquifer consists of cleaner and coarser sand. As known, the factors that control the spatial variability of groundwater quality. Three main factors were identified: (1) diffuse agricultural pollution sources; (2) dilution processes resulting from river water infiltrations, revealed by the $\delta^{18} \mathrm{O}_{\mathrm{H} 2 \mathrm{O}}$ and $\delta^{2} \mathrm{H}_{\mathrm{H} 2 \mathrm{O}}$ contents of groundwater; and (3) denitrification processes, controlled by the spatial variability of flood deposits governed by fluvial depositional processes [6].

According to the information from cutting of well drilling who have done by mining geological department of SMKN 1 Balikpapan at coordinate (UTM Zone 50) $0496153 \mathrm{mE}, 9865042 \mathrm{mN}$ has been reported unconfined aquifer at the location $\pm 5 \mathrm{~m}$ and after $5 \mathrm{~m}$ depth the drilling bit struck clay (Kampung Baru Formation) until $28 \mathrm{~m}$ depth, while in another location $0495369 \mathrm{mE}$ and $9864798 \mathrm{mN}$ at the depth of $28 \mathrm{~m}$ is found confined aquifer. From the above data showing that unconfined aquifer in the upper layer in the area of research has no interaction with other aquifer system. The aquifer which bordered by river beach and hilly topography has extents \pm 3.661 .814 square meters (calculated using GIS) with $5 \mathrm{~m}$ thickness, it has volume 131.825.304 cubic meters.

Fall head test to the soil sample T1 that was taken at $0495995 \mathrm{mE}$ dan $9865124 \mathrm{mN}$ at $1 \mathrm{~m}$ depth has result as follow:

Sample extents $\mathrm{A}=48.52 \mathrm{~cm}^{2}$ with length $\mathrm{L}=$ $40 \mathrm{~cm}$ and extents of inlet pipe $\mathrm{a}=2.01 \mathrm{~cm}^{2}$ the initial height of water in inlet $\mathrm{h}_{1}=61 \mathrm{~cm}$ and height of water in inlet after $\mathrm{t}=874$ seconds $\mathrm{h}_{2}=31 \mathrm{~cm}$. 


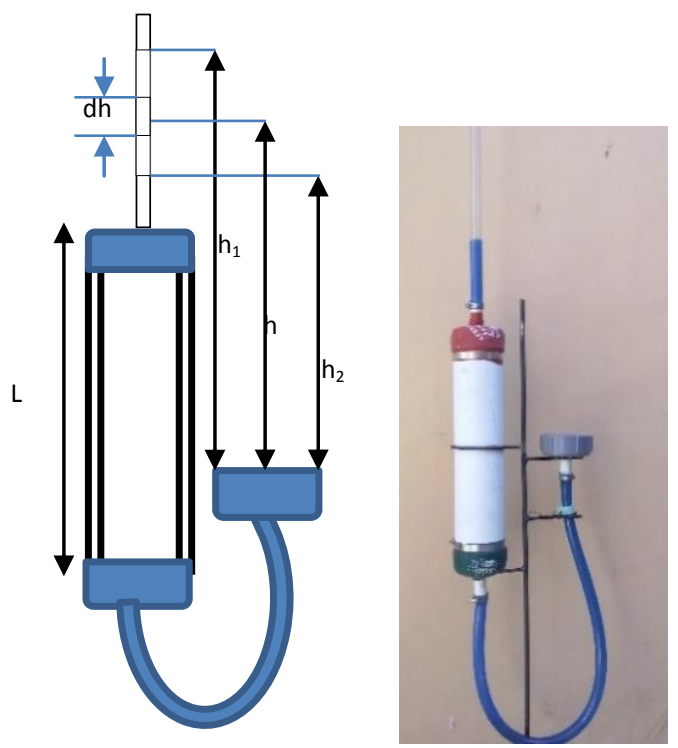

Figure 8. Scheme and Photo of Fall Head Test

According to Das, $2006 \mathrm{k}$ of can be solved using equation 2 to 10 where Debit of water in soil sample is :

$q=k \frac{h}{L} \cdot A$

And water debit in inlet:

$q=a \cdot \frac{d h}{d t}$

Relation the above equation

$k \frac{h}{L} \cdot A=-a \cdot \frac{d h}{d t}$

Coefficient of permeability $(\mathrm{k})$ can be determined as follow:

$d t=\frac{a L}{A k} \cdot\left(-\frac{d h}{h}\right)$.

$\int_{t_{1}=t}^{t_{0}=0} d t=-\frac{a L}{A k} \cdot \int_{h 2}^{h 1} \frac{d h}{h}$

$t=\frac{a L}{A k} \cdot \ln \left(\frac{h_{1}}{h_{2}}\right)$

$t=\frac{a L}{A k} \cdot 2.303 \log _{10}\left(\frac{h_{1}}{h_{2}}\right)$.

$k=2.303 \frac{a L}{A t} \cdot \log _{10} \frac{h_{1}}{h_{2}}$..............

Therefore $\mathrm{k}$ of sample $\mathrm{T} 1$ can be calculated as follows:

$k=2.303 \frac{2.01 \times 40}{48.52 \times 874} \cdot \log _{10} \frac{61}{31}$

$k=2.303 \times 1.896 \times 10^{-3} \times 0.294$

$k=1.284 \times 10^{-3} \mathrm{~cm} / \mathrm{s}$
The same test to three others sample (T2, T3, T4) have results as shown in the following table :

Tabel 2. Value of (k) result of fall head test

\begin{tabular}{|c|c|c|c|c|}
\hline \multirow{2}{*}{ No } & \multicolumn{2}{|c|}{ UTM Coordinate } & \multirow{2}{*}{$\begin{array}{l}\text { Time } \\
\text { second }\end{array}$} & \multirow{2}{*}{$\begin{array}{l}\text { Value of k } \\
\mathrm{cm} / \mathrm{s}\end{array}$} \\
\hline & Easting & Northing & & \\
\hline $\mathrm{T} 1$ & 0495995 & 9865124 & 874 & $1.284 \times 10^{-3}$ \\
\hline $\mathrm{T} 2$ & 0496150 & 9865090 & 586 & $1.915 \times 10^{-3}$ \\
\hline $\mathrm{T} 3$ & 0496373 & 9865027 & 473 & $2.372 \times 10^{-3}$ \\
\hline $\mathrm{T} 4$ & 0496761 & 9864567 & 98 & $11.45 \times 10^{-3}$ \\
\hline
\end{tabular}

Values of $\mathrm{k}$ show those increase toward the beach. That phenomenon is caused by soil layer in the land consist of fine sand mixed with silt and it change coarser gradually toward the beach. Fig. 11 shows correlation value of $\mathrm{k}$ with groundwater table height, the graph showing bigger $\mathrm{k}$ correlate with lower groundwater table.

Velocity of groundwater can be calculated using Law of Darcy[7][8][9], in the case of groundwater at S3 has $\mathrm{k}=\mathrm{k}=1.915 \mathrm{x}$ $10^{-3} \mathrm{~cm} / \mathrm{s}$ and S4 $\mathrm{k}=2.372 \times 10^{-3} \mathrm{~cm} / \mathrm{s}$

Distance between S3 and S4 can be solved using Pythagorean theorem:

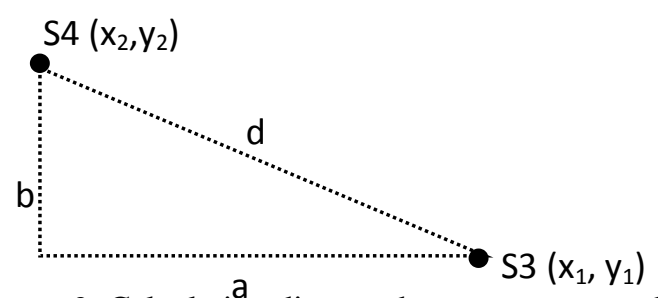

Figure 9. Calculation distance between two coordinate using Pythagorean theorem.

$$
d^{2}=a^{2}+b^{2}
$$

Where

$$
a=x_{2}-x_{1}
$$

and $\quad b=y_{2}-y_{1}$

$$
\begin{aligned}
& d^{2}=(-245.006)^{2}+(219.944)^{2} \\
& d^{2}=(-245.006)^{2}+(219.944)^{2} \\
& d^{2}=60027.94+48375.36 \\
& d^{2}=108403,303 \\
& d=\sqrt{108403.303}
\end{aligned}
$$




$$
d=329.24 \mathrm{~m}
$$

So the distance of S3 to S4 (L) = 329.24 meter. Other way to determine its distance, uses GIS Software like Fig.9.

Different height of DWL (head) S3 and S4 a $\Delta \mathrm{h}=3.595-2.403=1.192$ meter.

Then hydraulic gradient can be calculated as follow:

$$
\begin{aligned}
& i=\frac{\Delta h}{L} \ldots \ldots \ldots \ldots \ldots \ldots \\
& i=\frac{1.192}{329.24} \\
& i=3.62 \times 10^{-3}
\end{aligned}
$$

Average k of S3 and S4 :

$$
\mathrm{k}=\left(1.915 \times 10^{-3}+2.372 \times 10^{-3}\right) / 2
$$$$
\mathrm{k}=2.144 \times 10^{-3}
$$

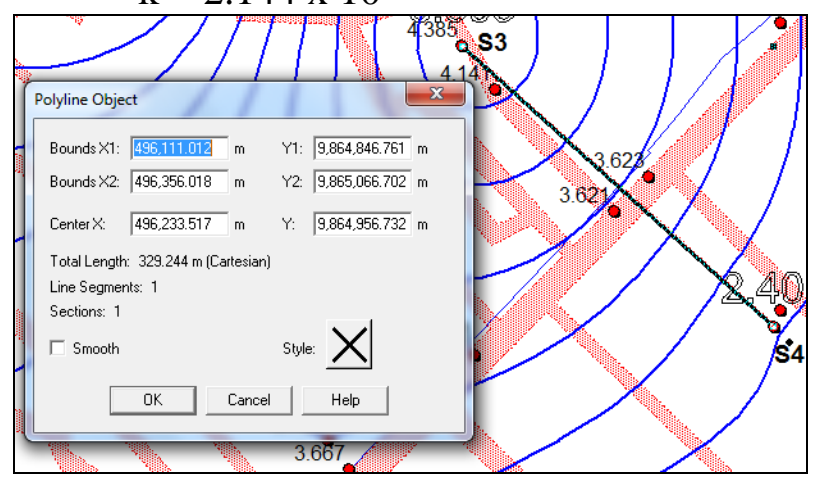

Figure 10. Determining the distance of S3 and S4 using GIS Software.

Velocity of groundwater that flow from S3 to S4 :

$$
\begin{aligned}
& v=k \cdot i \ldots \ldots \ldots \ldots \ldots \ldots \ldots \ldots \ldots \ldots \ldots \ldots \ldots \\
& v=2.144 \times 10^{-3} \times 3.62 \times 10^{-3} \\
& v=7.761 \times 10^{-6} \mathrm{~cm} / \mathrm{s}
\end{aligned}
$$

velocity of ground water flow also higher toward beach that mean ground water drained faster toward beach.

Meanwhile transmissibility (T) can be calculate using cutting of well drilling which has ever done at (UTM) $0496153 \mathrm{mE}$, $9865042 \mathrm{mN}$, it is known that aquifer thickness is $\pm 5 \mathrm{~m}$, then $\mathrm{T}$ at point $\mathrm{S} 3$ can be calculated as bellow:

$$
\mathrm{T}=\mathrm{k} . \mathrm{B}
$$

Where:

$$
\begin{aligned}
& \mathrm{T}=\text { transmissibility } \\
& \mathrm{B}=\text { aquifer thickness } \\
& \mathrm{k}=\text { permeability coefficient }
\end{aligned}
$$

Thickness of saturated aquifer is equal to the aquifer thickness minus depth of water table,

$$
\begin{aligned}
& \mathrm{B}=500-79 \\
& \mathrm{~B}=421 \mathrm{~cm} \\
& \mathrm{~T}=1.915 \times 10^{-3} \times 421 \\
& \mathrm{~T}=0.82 \mathrm{~cm}^{2} / \mathrm{s} \\
& \mathrm{T}=7.0848 \mathrm{~m}^{2} / \text { day. }
\end{aligned}
$$

In location with small $\mathrm{k}$ generally well will completely drained in two hours pumping with debit 10 up to 12 liters/minute and it has to wait about 2 hours for well to recover like as before. But at the location with higher $\mathrm{k}$ (S6) has steady flow it could be pumping continuously.

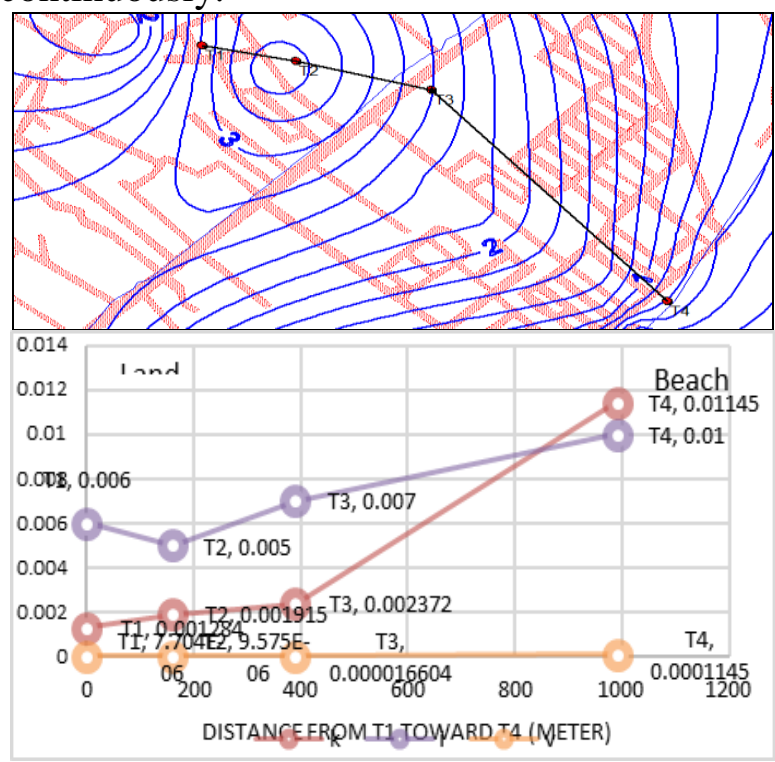

Figure 11. Correlation of k, i, and k at Location T1, T2, T3 dan T4 


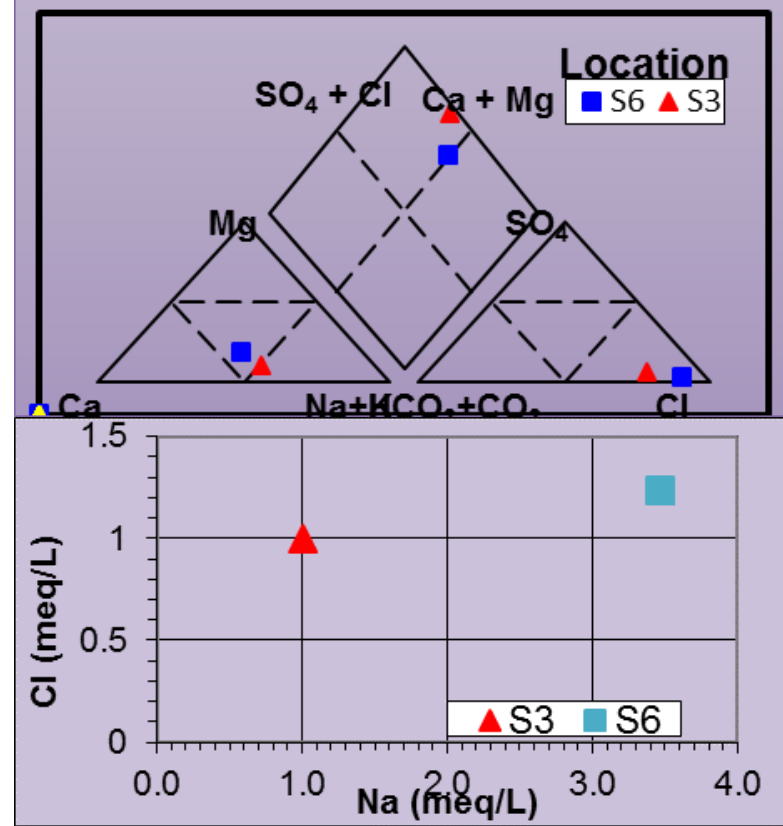

Figure 12. (a) Chemical Plot of S3 and S6 sample in Piper Diagram. (b) mixing of sea water.

Chemically, plot in Piper Diagram shows that anion of S3 sample is sodic type, meanwhile anion of S6 sample is no dominant type. And Cations both of S3 and S6 are chloride type (See Fig. 12). Laboratory test shows both of S3 and S6 samples have high hardness with concentration more than 180 $\mathrm{mg} / \mathrm{L}[10]$. It is also showing that S6 wells and its vicinity area has been contaminated by lead with concentration reaches $0.082 \mathrm{mg} / \mathrm{L}$ that is exceeded threshold limit 0.05 .

Landuse in the research area can be identified as follow : 1) housing area, 2) Manggrove area/swamp, 3)farm/plantation area, 4)river and river bank 5)beach area. From results of observation, large area of manggrove habitat is being converted to be housing area (See Fig.13).

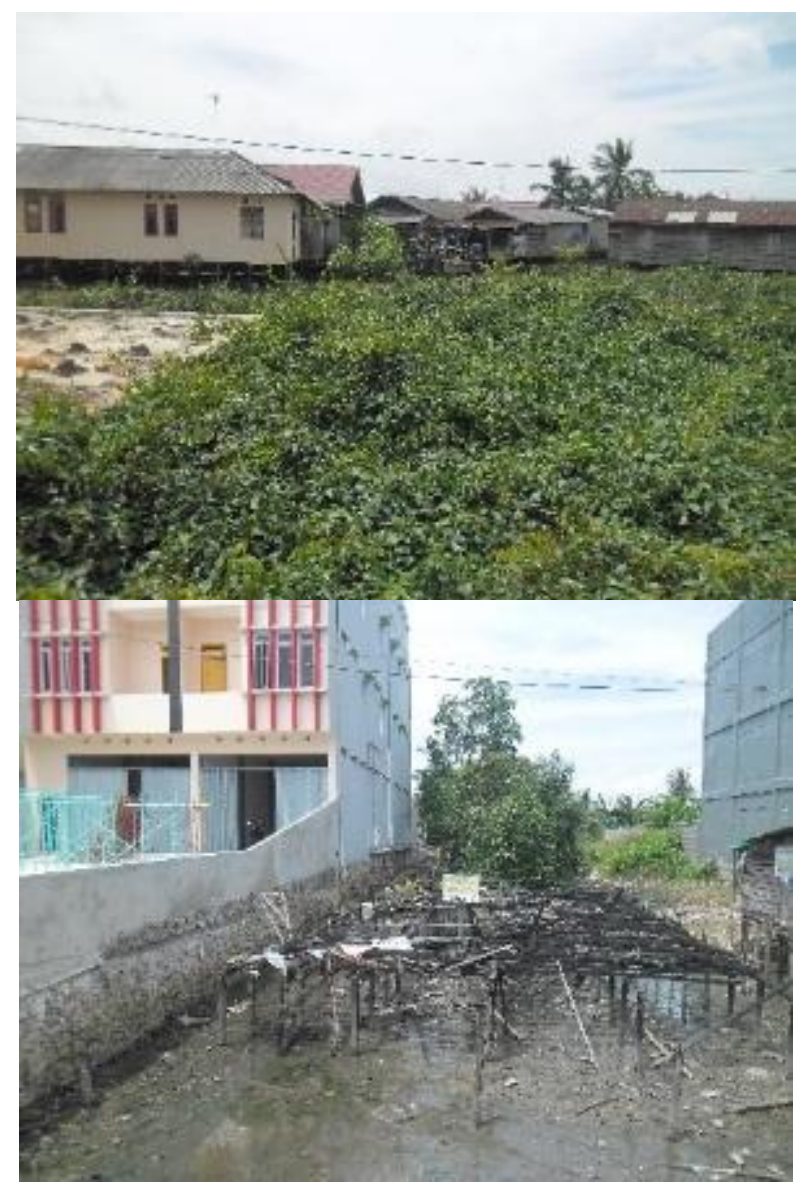

Figure 13. Conversion mangrove and swamp area become housing area RT.42 and shopping area on $\mathrm{Jl}$. Mulawarman.

Recently the existing farm and swamp area can be temporary buffer area for this aquifer system. But certainly it will be disappear sooner or later without regulation. Considering it has strategic location economically. Even flood plain of Manggar River Bank has become dense housing area. The Similar trend of conversion natural wetland to agricultural or urban land reported throughout the word [11] (See Fig.15). 


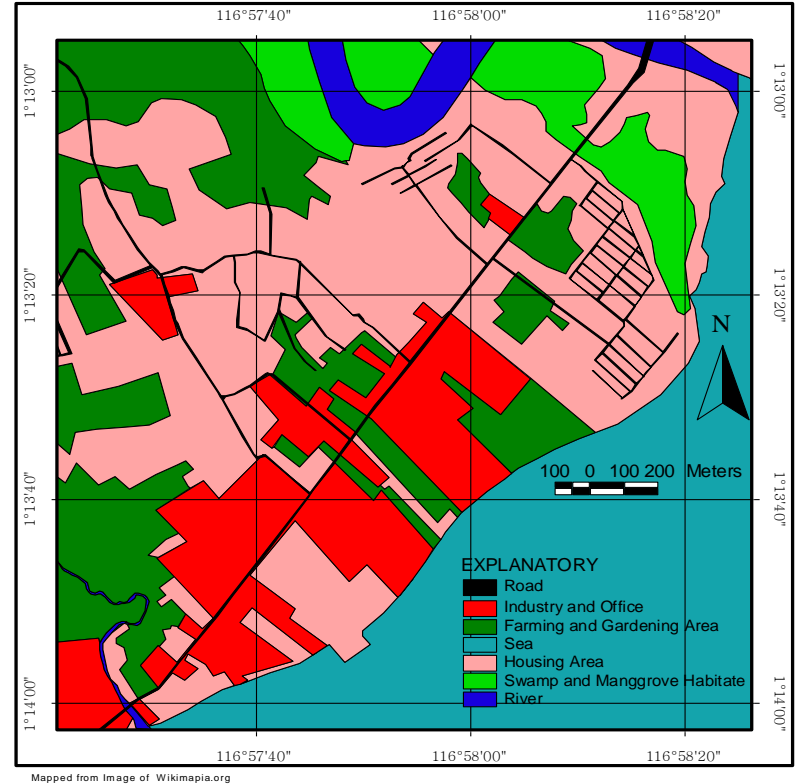

Figure 14. Land use map of research area.

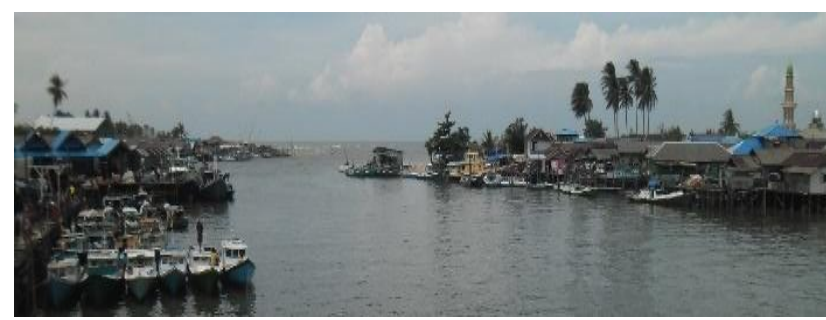

Figure 15. Dense housing area in flood plain downstream of Manggar River.

\section{Acknowledgments}

Special thank goes to the Directorate Research and Community Service, Ministry Research, Technology and Higher Education who has funded this research. The author also would like to extend gratitude to the management of State Polytechnics of Balikpapan who has facilitate us administratively so make this research possible. Special thank also goes to my colleagues at Civil Engineering Department of Poltekba who have shared knowledge and given advice during research.

\section{Conclusion and Recommendation}

In aquifer system groundwater flow from the center toward all direction (radial). The flowing velocity are greater toward beach which is correlated with $\mathrm{k}$ of aquifer and height of DWL. The geologic correlation to those parameter aquifer in the center part relatively finer and change coarser gradually toward beach. Those parameter and geologic feature also influence physical quality of ground water where closer to the beach ground water cleaner or more colorless. Chemically, Groundwater from the upstream and downstream have high hardness more than 180 $\mathrm{mg} / \mathrm{L}$, it has been mixed with seawater about 200-300 meter from beach groundwater near the beach is also contaminated by lead exceeds threshold limit. Cation of S3 is sodic type, and cation of S6 no dominant type, while cation both of S3 and S6 are chloride type.

Because the upstream of groundwater flow is housing and swamp area, the aquifer become vulnerable to biologic contaminant especially from bad sanitation system and bad septic tank quality. Most septic tank are made from precast low quality concrete that causes permeable and leaky. In order to prevent worse contaminant so it is highly recommended, there must be any regulation in order inhabitant on that area build replace leaky septic tank with impermeable septic tank.

\section{References}

[1] Slamet J. S, 1994, Kesehatan Lingkungan, Gadjah Mada University Press.page $84-85$.

Evaluasi Penataan wilayah dan Pengembangan Kota Balikpapan, BAPPEDA Kota Balikpapan, 2002

[3] Benito et al, Management of Alluvial Aquifers in Two Southern African Ephemeral Rivers: Implications for IWRM, Springer Science+Business Media B.V. 2009

[4] Burte et al, Use of water from small alluvial aquifers for irrigation in semi-arid, Regions, Revista Ciência Agronômica, v. 42, n. 3, p. 635-643, jul-set, Centro de Ciências Agrárias - Universidade Federal do Ceará, Fortaleza, CE, ISSN 1806-6690, 2011.

[5] Jihad, A M, Integration of Water Resources of the UpperAquifer in Amman-Zarqa Basin Based on Mathematical Modeling and GIS, 
Jordan, Vol 5, Frieberg Online Geology ISSN 1434-7512, 2005.

[6] Baillieux et.al, Regional water quality patterns in an alluvial aquifer: Direct and indirect influences of rivers, Journal of Contaminant Hydrology Volume 169, Elsevier, Pages 123131, 2014.

[7] Das, Principles of Geotechnical Engineering FIFTH EDITION, Tomson, Australia • Canada - Mexico - Singapore - Spain • United Kingdom • United States, 2006.

[8] Fetter, Applied Hydrology Third Edition, Macmillan College Publishing Company New York, 1994.

[9] Tod D. K, 1980, Groundwater Hydrology, John Wiley \& Son. Canada, 1994.

[10] Scott Bair \& Terry D. Lahm, Practical Problem in Ground Water Hydrology, Pearson Prentice Hall, Upper Saddle River, NJ07458, 2006

[11] Rains M. C, and Mount J. F, Origin of shallow ground water in an alluvial aquifer as determined by isotopic and chemical procedures, Groundwater Vol. 40. No. 5 : ProQuest p 552 -563, 2002 